Jurnal Pendidikan Dasar, 6 (1) Juni 2018

\title{
PENERAPAN MODEL PEMBELAJARAN BERBASIS MASALAH TERHADAP HASIL BELAJAR ILMU PENGETAHUAN ALAM PADA SISWA KELAS VI A SDN 13 NANGA PINOH
}

\author{
Lukas Nesim Nasi ${ }^{1}$, Rachmat Sahputra ${ }^{2}$, Nurul Apsari ${ }^{3}$ \\ ${ }^{1}$ Mahasiswa Lulusan Program Studi PGSD Tahun 2018 \\ ${ }^{2}$ Dosen Universitas Tanjung Pura \\ ${ }^{3}$ Dosen STKIP Melawi
}

Jl. RSUD Melawi km. 04 Kec. Nanga Pinoh Kab. Melawi Kalimantan Barat

Jl. Prof. Dr. H. Hadari Nawawi, Bansir Laut, Kota Pontianak, Kalimantan Barat

Lukasnesimnasi@gmail.com,rahmat_ui@yahoo.com, nurul.apsari89@gmail.com

\begin{abstract}
The purposed of this research is to finded out there are differences in SAINS student learned outcome before and after the applied problem based learning model in grade VI student of SDN 13 Nanga Pinoh. Besided this research also provide benefits for researcher, school, teachers, students and for ather researchers. This research used pre experimental type with One Group Pretest-Posttest design. Consist of four meetings. The population in this research has all students of grade VI A SDN 13 Nanga Pinoh, and sample selection in this research used saturated sample technique that is all member of population, with details of 9 female students and 13 male students. The data collection techniques in this research used multiple choice tes questions, and used content validity, instrument reliability KR 20, normality test and hypothesis test ( $\mathrm{t}$ test). The validation on this research based on exspert opinion was valid without notation. Result of reliability test was $r_{\text {count }}>r_{\text {table }}$ $(0,600>0,443$ on pre test and $0,937>0,443$ on post test $)$. Result of Normality test was $Z_{\text {hitung }}<Z_{\text {tabel }}(0,180<0,183$ on pre test and $0,118<0,183$ on post test).The results in this research was the average pre test is 55,11 and average of post test was 76,9. So it can be know the difference of the average is 21,79 . Then the hypothesis test is obtained $t_{\text {hitung }}<t_{\text {tabel }}(0,977<2,086) \mathrm{H}_{0}$ is rejected and $\mathrm{H}_{1}$ accepted.so it can be cocluded that there is significant diffeence of average before and after given the treatment. This means is The different from the application of problem based learning model to student learning outcome.

Keyword: student learning outcome. Problem based learning, Science
\end{abstract}

Abstrak: Tujuan penelitian yang dilaksanakan ini adalah untuk mengetahui
apakah terdapat perbedaan hasil belajar belajar IPA siswa sebelum dan setelah
diterapkan model pembelajaran berbasis masalah pada siswa kelas VI SDN 13
Nanga Pinoh. Selain itu juga penelitian ini memberikan manfaat bagi peneliti,
sekolah, guru, siswa dan bagi peneliti lainnya. Penelitian ini menggunakan
penelitian eksperimen jenis pre-eksperimental dengan desain One Group
Pretest-Posttest yang terdiri dari empat kali pertemuan. Populasi pada
penelitian ini adalah seluruh siswa kelas VI A SDN 13 Nanga Pinoh, dan
pemilihan sampel pada penelitian ini menggunakan teknik sampel jenuh yaitu
semua anggota populasi, terdapat 22 siswa dengan rincian 9 orang siswa
perempuan dan 13 orang siswa laki-laki. Adapun teknik pengumpulan data
pada penelitian ini menggunakan Tes soal pilihan ganda, dan menggunakan

1| J P D, p - I S S N : $2252-8156$, e - I S S N : $2579-3993$ 
validasi isi, reliabilitas instrumen KR 20, uji normalitas dan uji hipotesis (uji t). Validasi dalam penelitian ini berdasarkan pendapat ahli yaitu valid dengan catatan. Hasil perhitungan reliabilitas $r_{\text {hitung }}>r_{\text {tabel }}(0,600>0,443$ pada pre test dan $0,937>0,443$ pada post test). Uji normalitas dengan hasil $z_{\text {hitung }}<z_{\text {tabel }}$ $(0,180<0,183$ pada pre test dan $0,118<0,118$ pada post test $)$. Hasil dalam penelitian ini adalah rata-rata pretest yaitu 55,11 dan rata-rata post test yaitu 76,9. sehingga dapat diketahui selisih rata-ratanya yaitu 21,79 . Kemudian pada uji hipotesisnya di peroleh $t_{\text {hitung }}<t_{\text {tabel }}(0,977<2,086)$ maka Ho ditolak dan $\mathrm{H}_{1}$ diterima, sehingga dapat disimpulkan bahwa ada perbedaan rata-rata yang signifikan sebelum dan sesudah diberikan perlakuan, Artinya ada perbedaan dari penerapan model pembelajaran berbasis masalah terhadap hasil belajar siswa.

Kata Kunci :Hasil Belajar, Model Pembelajaran Berbasis Masalah, Ilmu Pengetahuan Alam (IPA).

endidikan adalah salah satu
kebutuhan hidup bagi manusia modern sekarang ini, tidak dapat dipungkiri bahwa pendidikan juga salah satu sarana yang dapat digunakan dalam mengembangkan diri. Setiap orang berhak mengembangkan diri melalui pemenuhan kebutuhan dasarnya, berhak mendapat pendidikan dan memperoleh manfaat dari ilmu pengetahuan dan teknologi, seni dan budaya, demi meningkatkan kualitas hidupnya dan demi kesejahteraan umat manusia. Pendidikan adalah sesuatu yang manusia ciptakan dengan sangat kompleks, oleh karena itu bebagai pandangan bermunculan dari berbagai sudut pandang. Suryabrata (2015: 293) berpendapat bahwa pendidikan adalah proses si pendidik dengan sengaja dan penuh tanggung jawab memberikan pengaruhnya kepada anak didik.

Berdasarkan hasil observasi di Kelas VI A SD Negeri 13 Nanga Pinoh desa Paal kecamatan Nanga Pinoh kabupaten Melawi pada hari Sabtu, 21 Januari 2017. Ada beberapa permasalahan yang ditemukan. Beberapa permasalahan yang ditemukan seperti: Pertama, Penggunaan metode yang konvensional yang masih dominan (belum menggunakan model pembelajaran yang bervariasi). Kedua, situasi kelas yang kurang kondusif (beberapa siswa sibuk dan berbicara dengan temannya). Ketiga, keterbatasaan penggunaan media pembelajaran (beberapa media pembelajaran rusak). Keempat, terdapat 14 dari 22 siswa yang belum mencapai KKM atau $40,3 \%$ siswa yang telah mencapai KKM pada pembelajara IPA.

Penerapan model pembelajaran yang berbeda perlu diterapkan yaitu, dengan menggunakan model pembelajaran berbasis masalah kepada siswa kelas VI A pada mata pelajaran IPA terhadap hasil belajar siswa dengan hipotesis bahwa model pembelajaran berbasis masalah 
dapat mempengaruhi hasil belajar IPA siswa. Hmelo-Silver (Eggen \& Kauchak, 2012: 307) berpendapat bahwa pembelajaran berbasis masalah adalah seperangkat model mengajar yang menggunakan masalah sebagai fokus untuk mengembangkan keterampilan pemecahan masalah, materi dan pengaturan diri. Model pembelajaran ini dapat melatih dan mengembangkan kemampuan siswa dalam menyelesaikan masalah dari kehidupan aktual siswa. Meyakini bahwa dengan diterapkannya model pembelajaran berbasis masalah ini pada siswa, maka hasil belajar siswa akan dapat dioptimalkan. Namun jika penerapan model pembelajaran ini diterapkan tanpa dukungan dan perhatian oleh pihak sekolah, maka model ini akan sulit untuk diterapkan pada siswa. Model pembelajaran berbasis masalah adalah suatu rangkaian aktivitas pembelajaran yang menekankan kepada proses penyelesaian masalah yang dihadapi secara ilmiah. Model ini bercirikan penggunaan masalah kehidupan nyata dengan meningkatkan keterampilan berpikir kritis serta menyelesaikan masalah, lalu mendapatkan pengetahuan dan konsepkonsep penting dalam pembelajaran. Model Pembelajaran ini mengutamakan proses belajar dimana tugas guru harus memfokuskan diri untuk membantu siswa mencapai hasil belajar yang diharapkan.
Tujuan dalam penelitian ini adalah untuk Mendeskripsikan hasil belajar siswa sebelum diterapkan model pembelajaran berbasis masalah, mendeskripsikan hasil belajar siswa setelah diterapkan model pembelajaran berbasis masalah dan untuk mengetahui perbedaan sebelum dan setelah penerapan model pembelajaran berbasis masalah terhadap hasil belajar IPA pada siswa kelas V A SDN 13 Nanga Pinoh.

Model pembelajaran berbasis masalah ini merupakan salah satu yang dilandasi aliran Konstruktivisme, dimana dibedakan menjadi dua yaitu berdasarkan pengetahuan logika dan pengetahuan sosial. Kegiatan pembelajaran berbasis masalah bermula dari suatu masalah dan memecahkannya adalah fokus pembelajarannya menurut Krajcik \& Blumenfeld (Eggen \& Kauchak, 2012: 307) sementara itu Scott dan Laura berpendapat bahwa pembelajaran berbasis masalah adalah seperangkat model mengajar yang menggunakan masalah sebagai fokus untuk mengembangkan keterampilan pemecahan masalah (Eggen \& Kauchak, 2012: 307), materi dan pengaturan diri. Dengan karakteristik dan fase penerapan model pembelajaran berbasis masalah sebagai berikut: Pembelajaran berfokus pada memecahkan masalah, tanggung jawab memecahkan masalah bertumpu pada siswa dan guru mendukung proses saat siswa mengerjakan 
masalah. Berikut fase-fase dalam menerapkan model pembelajaran berbasis masalah: mereview dan menyajikan masalah, Menyusun strategi, menerapkan strategi dan Membahas dan mengevaluasi hasil.

Hasil belajar merupakan salah satu indikator yang dapat menunjukan keberhasilan suatu proses pembelajaran atau model pembelajaran yang diterapkan. Susanto (2013: 5) berpendapat bahwa hasil belajar yaitu perubahan-perubahan yang terjadi pada diri siswa, baik yang menyangkut aspek kognitif, afektif dan psikomotorik sebagai hasil dari kegiatan belajar. Berdasarkan definisi yang ada dapat disimpulkan bahwa hasil belajar dapat dijadikan indikator keberhasilan dari suatu pembelajarandan hasil belajar adalah sesuatu yang diperoleh melalui proses belajar dan dapat diukur serta dapat diamati.

Penelitian yang menggunakan model pembelajaran berbasis masalah tentunya sudah pernah dilakukan sebelumnya baik terhadap hasil belajar dan pada mata pelajaran IPA. Pada penelitian ini memakai penelitian yang relevan dari penelitian Dwi Priyanto di Depok (Jakarta) dengan judul "Pembelajaran Berbasis Masalah dalam Meningkatkan Hasil Belajar Siswa” menurut analisis data diperoleh perhitungan dari $t_{\text {hitung }}=1,708$ dan $t_{\text {tabel }}=1,674$ sehingga $t_{\text {hitung }}>t_{\text {tabel }}$ ini menunjukan bahwa ada peningkatan hasil belajar siswa.

Ilmu Pengetahuan Alam (IPA) adalah disiplin Ilmu dalam artian sempit yaitu ilmu yang mempelajari kehidupan baik fisikal maupun kehidupan makhluk hidup dan tak hidup. Mulyono (2012: 187) menjelaskan bahwa IPA atau Sains adalah ilmu pengetahuan yang berhubungan atau yang membahas gejala alam. Carin dan Sund dalam Badarudin, 2011 (Rachmat Sahputra 2012: Vol.4) memberikan petunjuk tentang bagaimana seharusnya IPA diajarkan pada pendidikan dasar. Salah satu diantaranya adalah menanamkan ke dalam diri siswa keingintahuan akan alam sekitar, serta dapat memahami pejelasan-penjelasan ilmiah tentang fenomena alam. Menurut beberapa pengertian di atas dapat disimpulkan bahawa IPA adalah disiplin ilmu yang mempelajari alam semesta, gejala dan seluruh isinya.

Kebutuhan informasi ang sesuai dengan usia anak sekolah dasar juga mempengaruhi kemampuan anak. Berikut ini beberapa karakteristik anak menurut Aristoteles (Suryabrata, 2015: 185) adalah sebagai berikut: 
Tabel. 1 Karakteristik Perkembangan Anak

\begin{tabular}{ccl}
\hline Fase & Usia & \multicolumn{1}{c}{ Karakter } \\
\hline I & $0 ; 0-7 ; 0$ & Masa anak kecil ke masa bermain \\
II & $7 ; 0-14 ; 0$ & $\begin{array}{l}\text { Masa anak, masa belajar atau masa belajar } \\
\text { rendah }\end{array}$ \\
III $\quad 14 ; 0-21 ; 0$ & $\begin{array}{l}\text { Masa remaja atau masa pubertas dan masa } \\
\text { peralihan remaja menjadi dewasa }\end{array}$ \\
\hline
\end{tabular}

Piaget (Susanto, 2013: 77) berpendapat bahwa, pada usia 7-11 tahun (tahap operasional konnkret) peserta didik sudah mulai memahami aspek-aspek komulatif materi, misalnya volume dan jumlah dan mempunyai kemampuan memahami cara mengombinasikan beberapa golongan benda yang bervariasi tingkatannya.

Kerangka berfikir dalam penelitian ini berdasarkan asumsi hasil Belajar siswa yang rendah, setelah itu berdasarkan hasil obervasi diperolah $59,7 \%$ siswa belum mencapai KKM. pembelajaran dikelas yang belum kondusif serta penggunaan metode konvensional yang masih dominan, selanjutnya diterapkan model pembelajaran berbasis masalah dan diperoleh asumsi bahwa terdapat perbedaan yang signifikan sebelum dan setelah penerapan model pembelajaran berbasis masalah. Berdasarkan asumsi bahwa terdapat perbedaan hasil belajar pada siswa sebelum dan setelah penerapan model.

\section{METODE PENELITIAN}

Penelitian yang digunakan adalah jenis penelitian pre-eksperimental, secara khusus pada one group pre-post test design. Penelitian eksperimental menggunakan suatu percobaan yang dirancang secara khusus guna membangkitkan data yang diperlukan untuk menjawab pertanyaan penelitian. Margono (2010: 110) berpendapat bahwa penelitian eksperimental adalah penelitian dengan melakukan percobaan terhadap kelompok eksperimen. kepada setiap kelompok diberlakukan perlakuanperlakuan tertentu. Desain one group prepost test ini digunakan untuk mengetahui hasil belajar siswa baik sebelum diberikan treatment ataupun sesudahnya. Untuk mengetahui hasil belajar serta kemampuan siswa maka dilakukan pre test diawal atau sebelum adanya treatment atau perlakuan.

$$
\text { X1 : } 0 \text { : X2 }
$$

Keterangan: 1. X1 : Pre test

2. $\mathrm{O}$ : Treatment

3. X2 : Post Test

One pre-post test design

(Sugiyono 2014: 116) 
Terdapat dua variabel dalam penelitian ini yaitu: Variabel bebas, pada penelitian ini adalah variabel yang akan mempengaruhi hasil belajar siswa, yaitu model pembelajaran berbasis masalahdan variabel terikat, pada penelitian ini adalah variabel yang akan terpengaruh oleh penerapan model pembelajaran, yaitu hasil belajar siswa.

Populasi adalah keseluruhan dari subyek penelitian yang dapat berupa orang, benda atau suatu hal yang dapat memberikan informasi untuk penelitian. Pada penelitian ini populasi yang ditetapkan adalah seluruh siswa kelas VI A SD N13 Nanga Pinoh yang berjumlah 22 siswa yang tersiri atas 13 siswa perempuan dan 9 siswa laki-laki adalah sampel dalam penelitian ini. Sampel adalah bagian atau jumlah dan karakteristik yang dimiliki oleh populasi dimana dapat mewakili populasi itu sendiri. Pada penelitian ini akan menggunakan teknik sampling jenuh. Dengan demikian seluruh siswa kelas VI A SD Negeri 13 Nanga Pinoh yang jumlah 22 siswa terdiri dari 13 siswa perempuan dan 9 siswa laki-laki adalah sampel dalam penelitian ini.

Pengumpulan data pada penelitian ini menggunakan teknik pengukuran khususnya pada alat ukur tes. Penelitian ini mengkaji dua variabel, yaitu pengaruh model pembelajaran berbasis masalah dan hasil belajar IPA siswa. Untuk mengetahui dua variabel tersebut mempengaruhi atau terpengaruh maka menggunakan tes.

Validitas adalah suatu konsep yang berkaitan dengan sejauh mana tes telah mengukur apa yang seharusnya diukur. Pada penelitian ini jenis validitas yang digunakan adalah validitas isi (Content Validity). Pengujian reliabilitas instrument pada penelitian ini adalah reliabilitas internal Consistency dengan hasil soal pre test dan soal post test adalah $0,600>0,443$ dan 0,937 $>0,443$ maka dapat disimpulkan bahwa instrument penelitian tersebut reliabel karena hasil $r_{\text {hitung }}>r_{\text {tabel }}$. Taraf reliabelnya adalah tinggi karena berada pada rentan 0,60-0,80, dengan demikian maka soal tersebut dapat di gunakan pada penelitian di SDN 13 Nanga PinohData dalam penelitian ini haruslah berdistribusi normal dan pengujian data pada penelitian ini menggunakan Uji normalitas dengan menggunakan rumus tabel Liliefors. Setelah data berdistribusi normal maka selanjutnya data akan di uji hipotesis dengan menggunakan Uji t, dengan keterangan $\mathrm{H}_{\mathrm{o}}$ : $\mu_{1}=\mu_{2} \quad$ (tidak ada perbedaan yang signifikan sebelum dan setelah diberikan perlakuan) atau $\mathrm{H}_{1}: \mu_{1} \neq \mu_{2}$ (ada perbedaan yang signifikan sebelum dan setelah diberikan perlakuan).

\section{HASIL DAN PEMBAHASAN}

Hasil Pre test dan Post test yang dilaksanakan pada siswa kelas VI A SDN 13 Nanga Pinoh berdasarkan perbedaan hasil belajar siswa dapat dilihat dari hasil sebelum 
dan setelah penerapan model pembelajaran berbasis masalah pada penelitian ini, dengan demikian dapat diketahui apakah terdapat perbedaan sebelum dan setelah penerapan model pembelajaran berbasis masalah perhadap hasil belajar IPA siswa kelas VI A SDN 13 Nanga Pinoh.

Tabel.3 Perhitungan rata-rata skor pre test dan skor post test:

\begin{tabular}{cccc}
\hline Soal & $\begin{array}{c}\text { Jumlah } \\
\text { Siswa }\end{array}$ & $\begin{array}{c}\text { Rata-Rata } \\
\text { Skor }\end{array}$ & $\begin{array}{c}\text { Selisih } \\
\text { Rata-Rata }\end{array}$ \\
\hline Pre test & 22 & 55,11 & 21,79 \\
Post test & 22 & 76,9 & \\
\hline
\end{tabular}

Perbandingan antara rata-rata skor pre test dan skor post test menunjukan adanya selisih yang signifikan sebesar 21,79 dari rata rata pre test sebesar 55,11 dan rata-rata post test sebesar 76,9

Hasil uji normalitas berdasarkan perbandingan $Z_{\text {hitung }}$ dan $Z_{\text {tabel }}$ adalah sebagai beikut:

Tabel.4 Hasil Uji Normalitas pre test dan post test

\begin{tabular}{cccc}
\hline Soal & $\mathrm{z}_{\text {hitung }}$ & $\mathrm{z}_{\text {table }}$ & Kesimpulan \\
\hline Pre test & 0,180 & 0,183 & $\mathrm{z}_{\text {hitung }}<\mathrm{z}_{\text {tabel }}$ \\
Post test & 0,118 & 0,183 & $\mathrm{z}_{\text {hitung }}<\mathrm{z}_{\text {tabel }}$ \\
\hline
\end{tabular}

Berdasarkan tabel hasil uji normalitas pre test dan post test di atas diperoleh perhitungan $0,190>0,180$ pada pre test atau $\mathrm{Z}$ tabel $>\mathrm{Z}$ hitung maka data pada pre test berdistribusi normal, dan perolehan perhitungan $0,190>0,118$ pada post test atau $Z_{\text {hitung }}<Z_{\text {tabel }}$ maka data pada post test juga berdistribusi normal.
Berdasarkan perhitungan uji hipotesis dari hasil pre test dan post test siswa diperoleh hasil sebagai berikut:

Tabel.5 Hasil Uji Hipotesis (Uji t)

\begin{tabular}{ccc}
\hline t hitung & $\mathrm{t}$ table & Kesimpulan \\
\hline 0,977 & 2,086 & $\mathrm{t}_{\text {hitung }}<\mathrm{t}_{\text {tabel }}$ \\
\hline
\end{tabular}

Kesimpulan $\mathrm{t}_{\text {hitung }}<\mathrm{t}_{\text {tabel }}$ maka $\mathrm{H}_{0}$ ditolak dan $\mathrm{H}_{\mathrm{a}}$ diterima, dimana hasil belajar IPA siswa sebelum diterapkan model $\neq$ hasil belajar siswa setelah diterapkan model dengan perbedaan sebesar $97,7 \%$ terhadap hasil belajar IPA pada siswa kelas VI ASDN 13 Nanga Pinoh. Artinya $H_{1}: \mu_{1} \neq \mu_{2}$ atau terdapat perbedaan yang signifikan sebelum dan setelah penerapan model pembelajaran berbasis masalah terhadap hasil belajar IPA pada siswa kelas VI A SDN 13 Nanga Pinoh

Permasalahan yang sering terjadi dalam pembelajaran akan berdampak bagi hasil belajar siswa. Berdasarkan observasi pada SDN 13 Nanga Pinoh ditemukan beberapa permasalahan seperti, penggunaan metode yang konvensional yang masih dominan, situasi kelas yang kurang kondusif, keterbatasaan penggunaan media pembelajaran, dan terdapat 14 dari 22 siswa yang belum mencapai KKM pada pembelajaran IPA. Berdasarkan permasalahan yang ada maka dalam penelitian ini diperlukan model pembelajaran yang baru. Penelitian yang 
peneliti laksanakan yaitu dimulai pada tanggal 21 Agustus 2017.

Perhitungan hasil pre test diperoleh skor dengan angka terendah yaitu 33,3 dan angka tertinggi yaitu 86,6 , kemudian setelah menerapkan model pembelajaran berbasis masalah (posttest) pada penelitian ini diperoleh skor dengan angka terendah yaitu 53,3 dan angka tertinggi yaitu 93,3. Setelah dilakukan analisis diperoleh rata-rata skor pada pretest adalah sebesar adalah 55,1, serta rata-rata skor pada posttest dalah 76,9 dngan selisih rata-ratanya adalah 21,79. Berdasarkan hasil penelitian, Uji Normalitas pada pre test diperoleh $\mathrm{Z}_{\text {hitung }}$ 0,180 dan $\mathrm{Z}_{\text {tabel }} 0,183$. Pada post test $\mathrm{Z}_{\text {hitung }}$ 0,118 dan $z_{\text {tabel }} 0,183$ dari kedua test yang diberikan menunjukan bahwa data yang diperoleh adalah berdistribusi normal. Pengujian hipotesis hasil pre test dan post test menunjukan bahwa $\mathrm{t}_{\text {hitung }}<\mathrm{t}_{\text {tabel }}$ dengan angka $0,977<2,086$, maka $\mathrm{H}_{0}$ ditolak dan $\mathrm{H}_{\mathrm{a}}$ diterima, sehingga dapat disimpulkan bahwa ada perbedaan rata-rata yang signifikan sebelum dan sesudah diberikan perlakuan, Artinya ada perbedaan dari penerapan model pembelajaran berbasis masalah terhadap hasil belajar IPA pada siswa kelas VI A SDN 13 Nanga Pinoh.

\section{SIMPULAN}

Berdasarkan hasil penelitian dan pembahasan, dapat disimpulkan bahwa ada perbedaan hasil belajar IPA yang signifikan antara sebelum dan setelah penerapan model pembelajaran berbasis masalah, ini membuktikan bahwa penerapan model pembelajaran berbasis masalah berpengaruh terhadap hasil belajar IPA siswa kelas VI A SDN 13 Nanga Pinoh. Hal tersebut dapat diketahui setelah dilakukan analisis diperoleh rata-rata skor pada pretest adalah sebesar adalah 55,11, serta rata-rata skor pada posttest adalah 76,9 dan selisih rataratanya adalah 21,79 . Selain itu juga dapat dilihat dari pengujian hipotesis dengan hasil pretest dan posttest menunjukan bahwa $\mathrm{t}_{\text {hitung }}<\mathrm{t}_{\text {tabel }}(0,977<2,086)$ maka $\mathrm{H}_{0}$ ditolak dan $\mathrm{H}_{\mathrm{a}}$ diterima, sehingga dapat disimpulkan bahwa ada perbedaan rata-rata yang signifikan sebelum dan sesudah diberikan perlakuan, Artinya ada pengaruh dari penerapan model pembelajaran berbasis masalah terhadap hasil belajar IPA siswa kelas VI A SDN 13 Nanga Pinoh.

\section{DAFTAR PUSTAKA}

Kauchak dan Eggen, P. 2012, Strategi dan model Pembelajaran. diterjemahkan oleh Satrio wahono. Jakarta: Indeks.

Margono, S. 2010. Metodologi Penelitian Pendidikan. Jakarta: Rineka cipta.

Mulyono. 2012. Kamus Kimia. Jakarta: Bumi Aksara.

Priyanto, D. 2007. Pembelajaran Berbasis Masalah dalam Meningkatkan Hasil Belajarn Siswa. (online). Skripsi. Tersedia di http://repository.uinjkt.ac.id/ . Diakses pada 16 maret 2016. 
Jurnal Pendidikan Dasar, 6 (1) Juni 2018

Sahputra, R. 2012. "Peningkatan minat belajar siswa dengan pendekatan inkuiri pada pelajaran ilmu pengetahuan alam (IPA) sekolah dasar".(Online), Jurnal pendidikan.

Tersedia di http://jurnal.untan.ac.id/.

Diakses pada 17 November 2017.
Suryabrata. 2015. Psikologi pendidikan. Jakarta: Raja Grafindo Persada.

Susanto, A. 2013. Teori belajar dan pembelajaran di sekolah dasar. Jakarta: Fajar Interpratama Mandiri. 